\title{
AN ANALYSIS OF YOUTH BEHAVIOR ON SOCIAL NETWORKS DURING THE COVID-19 PANDEMIC. EVIDENCE FROM ROMANIA
}

\author{
Andreea BARBU \\ University POLITEHNICA of Bucharest, Bucharest, Romania \\ barbu.andreeab@yahoo.com
}

\begin{abstract}
The year 2020 represents a year of balance for both the economic and the social environment. Since March 2020, when the World Health Organization declared a state of pandemic for COVID-19, everything has changed for people's personal or professional lives. Information about the new virus is spread globally, through the authorities, television, specialized websites, or even social networks. Given that social networks were heavily used even before the COVID-19 pandemic, it is interesting to investigate how they were used during the pandemic by users. The goal of this paper is to determine how young people used social networks during this period. In this sense, quantitative research has been developed based on a questionnaire that was addressed to the 4th year students specializing in Engineering and Business Management at the Polytechnic University of Bucharest. The pilot study presented in this paper investigates a sample of young people from Bucharest, Romania, analyzing the reasons why young people use social networks when it comes to the situation of the new virus, but also the reasons why they now use social networks, following their new behavior on these platforms during this period. Also, the paper analyses the time spent by respondents on social networks before the pandemic and after it started. According to this study, Twitter, Skype, and Facebook are the most used social networks during the quarantine days. Young people use the most of social networks for relaxation, while when they use Instagram, they often end up buying things that they see posted there.
\end{abstract}

Keywords: COVID-19, social networks, young people's behavior.

\section{INTRODUCTION}

From December 2019, everyone began to be affected by the effects of the COVID -19 virus, an infectious disease caused by the most recently discovered coronavirus. Children, young people, adults, or the elderly, are all affected to some extent by this virus, either directly or indirectly. Our lives, of all, have undergone great changes with the appearance of this virus, and whether we like it or not, whether we believe in its existence or not, we all need to inform ourselves, to protect ourselves to prevent the appearance of this virus, for the sake of our health and those around us.

During this pandemic time, the media and social networks played a very important role in presenting the situation generated by COVID-19 and transmitting the necessary information to successfully manage any 
Barbu A.

AN ANALYSIS OF YOUTH BEHAVIOR ON SOCIAL MEDIA NETWORKS DURING THE COVID-19 PANDEMIC. EVIDENCE FROM ROMANIA

positive cases tested around us. In the situations presented in the media but also in certain studies (World Health Organization, 2020a), it was presented that the elderly population is the most affected by this virus, which made the young population somehow divided into 2 parts: a part that is concerned about their health, their parents' and grandparents' health, as well as older loved ones around them, and a part of those young people who are more relaxed, as they are not directly part of a vulnerable group to the virus. However, whether they are more relaxed or more cautious, more sceptical, or more credible, young people continue to use social media, a favourite medium even before the pandemic situation.

Given the fact that a lot of information about COVID-19 is posted everywhere on the Internet, but also on television, this study aims to determine the role of social networks in the lives of young people during this period and what exactly are the reasons why young people use social networks in this context of the evolution of the virus.

\section{LITERATURE REVIEW}

\subsection{Social media and social networks}

Social media is considered a tool (Michaelidou et al., 2011), that consists of Internet-based applications, that allow people to communicate, create, or share content (Kaplan and Haenlein, 2010). Lately, these networks have begun to be used even within companies, employees communicating, or exchanging various files much more easily (Leonardi et al, 2013). Apart from these social media platforms, both people and companies use social networks, those being networks that promote the exchange of information between users (Cohen et al., 2018).

In July 2020, the most used social networks regarding the number of active users (in millions) were Facebook with 2606 million monthly active users, WhatsApp and YouTube with 2 billion monthly active users each of them, followed by Facebook Messenger, Weixin/ WeChat, Instagram, or TikTok (The Statista Portal, 2020). 
Barbu A.

AN ANALYSIS OF YOUTH BEHAVIOR ON SOCIAL MEDIA NETWORKS DURING THE COVID-19 PANDEMIC. EVIDENCE FROM ROMANIA

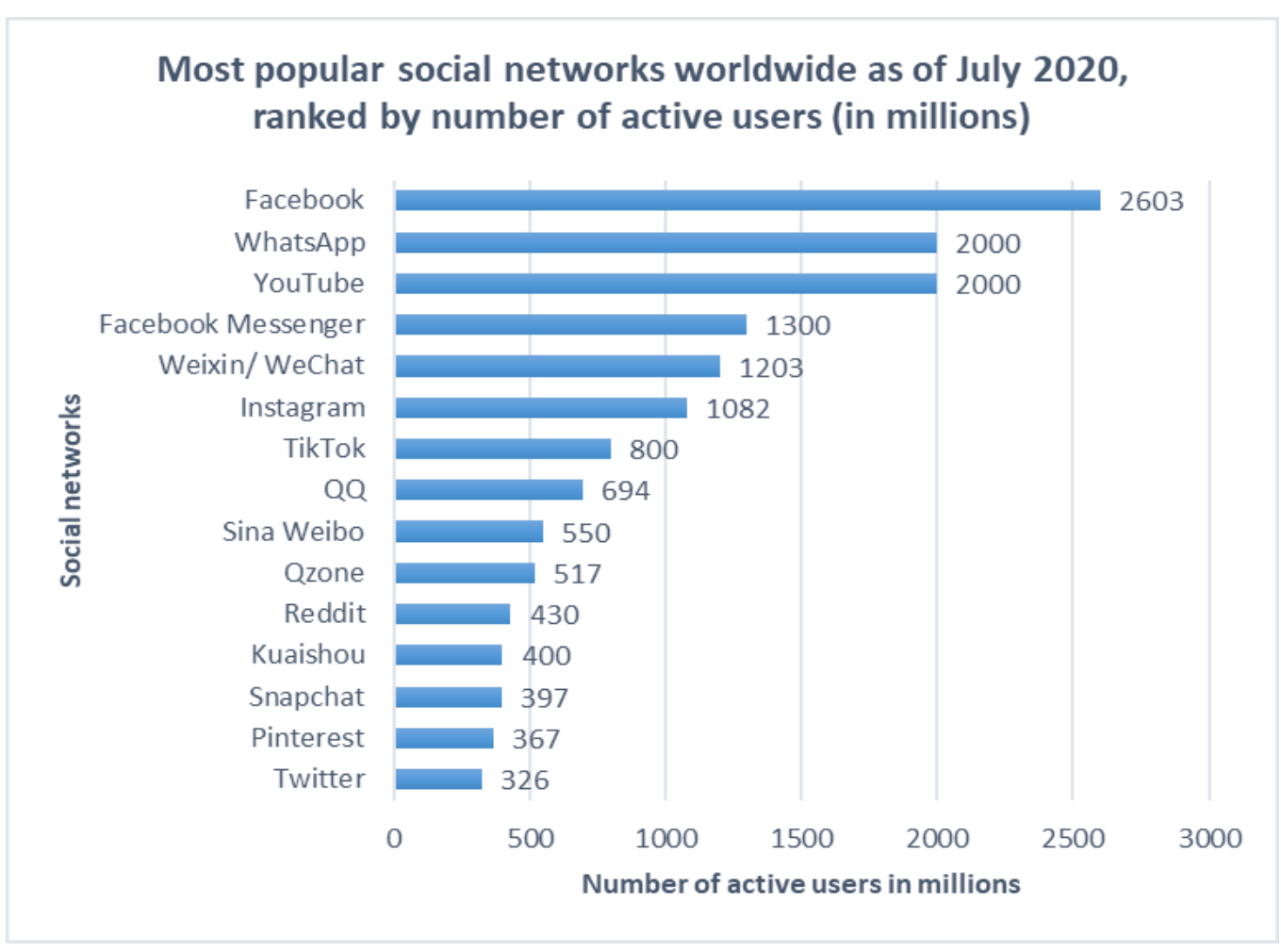

FIGURE 1.MOST POPULAR SOCIAL NETWORKS WORLDWIDE AS OF JULY 2020, RANKED BY NUMBER OF ACTIVE USERS (IN MILLIONS)

Source: adapted from The Statista Portal, 2020 https://www.statista.com/statistics/272014/global-social-networksranked-by-number-of-users/

\subsection{COVID-19}

In December 2019, in Wuhan, China, it was discovered a new coronavirus disease (COVID-19) which started from the identification of more cases of atypical pneumonia (Al Hasan et al., 2020). Not long after, this new virus was discovered in other parts of the world, its spread beginning to be worldwide. On 30 July 2020, there have been reported 16.812.755 confirmed cases of COVID-19 worldwide, including 662.095 deaths (World Health Organization, 2020b). The rapid spread, lack of treatment, and the deadly effects have made this virus a general concern of all people, even if it has its origin in curiosity, fear, involvement, or desire to change things.

With the appearance of this virus, researchers from all over the world have started to conduct studies to determine either the epidemiology, causes, clinical manifestation and diagnosis or prevention and control. In March 2020, the largest portion of the papers was related to causes (38\%), followed by epidemiology (29\%) (Adhikari et al., 2020). Since then, a lot of academics and specialists from all fields have started to study the new virus and everything related to its appearance and coexistence with it. It analyses the 
Barbu A.

AN ANALYSIS OF YOUTH BEHAVIOR ON SOCIAL MEDIA NETWORKS DURING THE COVID-19 PANDEMIC.

EVIDENCE FROM ROMANIA

economic impact, the impact on the climate, or even the lifestyle, being organized in this sense special issues in various specialized magazines or conferences that focus on COVID-19.

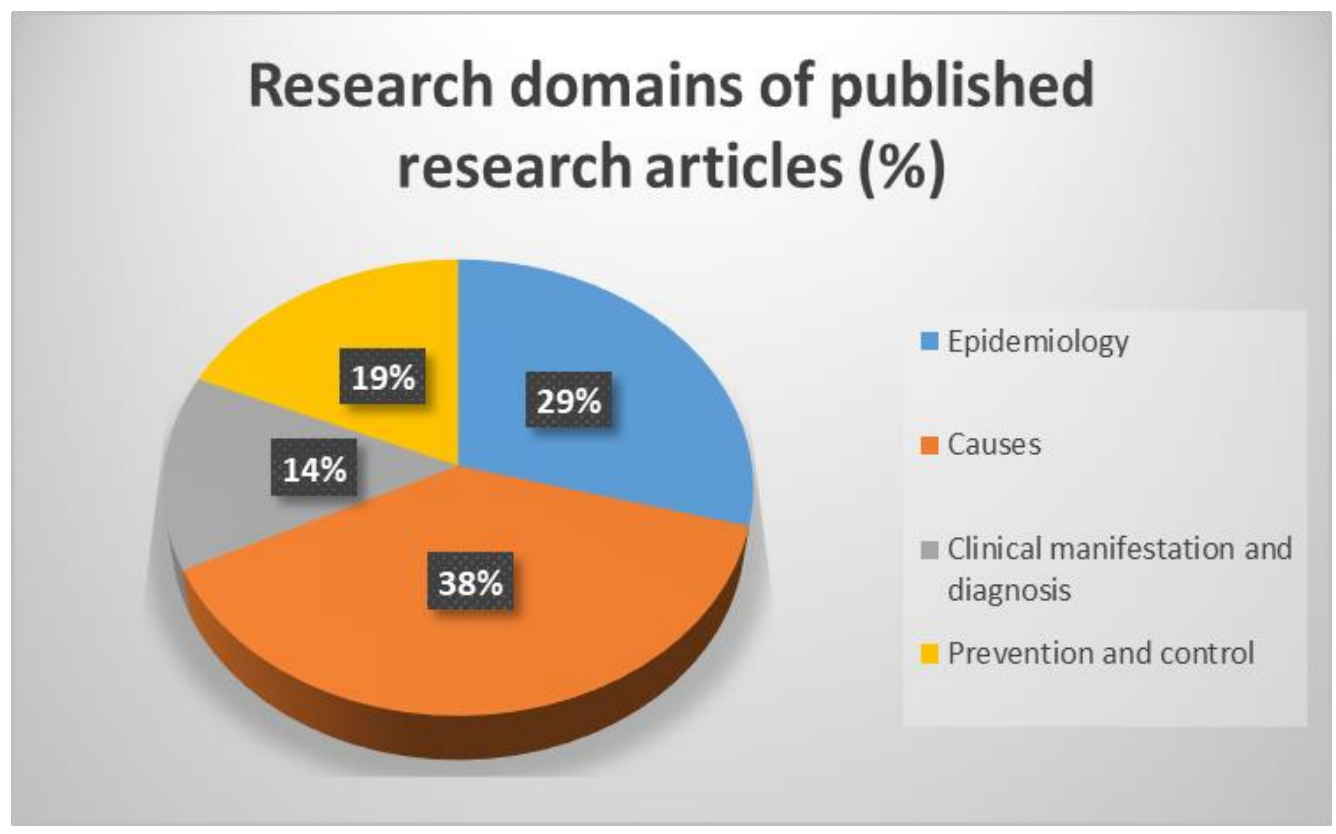

FIgURE 2. RESEARCH DOMAINS OF PUBLISHED RESEARCH ARTICLES IN MARCH 2020 (\%)

Source: adapted from Adhikari, S., Meng, S., Wu, Y. et al. Epidemiology, causes, clinical manifestation and diagnosis, prevention and control of coronavirus disease (COVID-19) during the early outbreak period: a scoping review. Infect Dis Poverty 9, 29 (2020)

Even though there is an official site where people can read Coronavirus disease (COVID-2019) press briefings (World Health Organization, 2020a), people around the world can see a lot of news, videos, and information about the pandemic situation on any social network. The problem is that not all sources are reliable, credible, or verified, which is why some people end up being misinformed or forming certain misconceptions about the situation we are going through. In any case, they continue to use social networks, both for personal reasons and for reasons related to the new coronavirus.

\subsection{The research aim}

The emergence of the COVID-19 virus has brought many changes in the lives of people and companies. Since its inception, researchers in all fields have begun to study various direct aspects of the virus on our lives. On the other hand, although there are many articles about social networks, very few analyze the relationship between them and the effects that the virus has on our lives. Taking into 
account the fact that young people are especially those who mainly use social networks (Ballard et al., 2019), this study aims to analyze their behavior on social networks with the onset of the pandemic.

Following the outbreak of the pandemic and the isolation situation at home, the level of stress in people's lives has increased, as they feel vulnerable to the virus (Slovic et al., 2005). They need to find the moral and physical support to get through this period but often they do not know how to do it. A study by Pizzoli et al. (2020) shows that audio clips can help reduce people's perceived stress and preoccupation with COVID-19 thoughts. Taking into account the fact that all kinds of audio clips circulate on social networks or that audio conversations can be made; the author wants to test whether social networks contribute to the relaxation of individuals.

During this period, many changes have appeared in the educational environment, the study hours being conducted online. In one of the researches on how the use of the Internet helps the educational environment, Daoud et al. (2020) show that socialization is a function of education that has the role of preparing students to participate in society in the future. Its analysis indicated that Internet access at home positively influences the social skills of students. Taking into account this information, this paper aims to verify whether the use of social networks influences the socialization of young people in isolation in their own homes.

Anastasiei and Dospinescu (2017) had analyzed the relationship between Facebook and buying behavior. According to them, if a company or a person wants to sell a technical product via social network, the message is very important, in this case, the rational message having more impact on individuals than the emotional messages. On social networks, there are a lot of people and companies that post their opinion, their experience with a product or a service, or their recommendations, these messages reaching many of the internet users. It is interesting to test if, for the young ones, social networks can influence shopping behavior.

A study by Khodabandeh and Lindh (2020) shows that brand image is very important when it comes to buying intention on social networks, while the effect of the activities of influencers on these social networks on the intention to buy is mediated by the brand. For this reason, companies should focus on two main directions when it comes to activity on social networks: strengthening the brand and building relationships with influencers to present their goods or services. Taking into account these important activities in the online environment, one of the goals of this paper is to test the link between the buying behavior of young people during the pandemic state and the use of social networks.

In China, a study on the level of boredom and mood of adults was conducted in the first weeks after the declaration of the pandemic state (Chao et al., 2020), this study being applied to a sample of 917 people. The results of the study indicated that the effects of boredom on stress were mediated by the use of social networks, boredom being a rather dangerous concept for people's health during this 
period. Moreover, another study that analyzed changes in behavior on social networks of young people from adolescence to adulthood (Stockdale and Coyne, 2020) draws attention to the fact that, over time, the use of social networks to alleviate boredom increased. This situation has been associated with financial stress and anxiety. Taking into account these aspects, the author wants to see if, in Romania, young people in isolation have started to use social networks more and more often because of boredom, being also stressed by the new situation.

In terms of communication on social networks, they have long gone beyond the personal sphere and began to be used for professional purposes. Thus, through social networks, people can collaborate more easily, can find professional and personal support, and can even have academic discussions. Although there are many advantages to use these networks to communicate with colleagues, research points out that this form of online communication can be dangerous when personal and professional life intertwine too much, which can affect the professional image of individuals. Taking into account these aspects of communication between people who have a job, it is desired that through this paper to determine how the use of social networks in the analyzed period influenced the communication with colleagues among young people.

Taking into account all of the hypotheses mentioned above, the object of this paper is to analyse people's behaviour regarding the use of social networks before and after the COVID-19, focusing on young people's behaviour from Bucharest, Romania. To achieve this goal, daily use before and after COVID-19 was analysed. The focus was then on the situation after the outbreak of the pandemic, the paper analysing both the personal reasons why young people continue to use social media during this period and the reasons directly related to the new virus for which they use social media platforms.

\section{METHODOLOGY}

For this study, the author developed a questionnaire that was applied online in March and April 2020, during the Romanian lockdown situation caused by COVID-19. This questionnaire was applied to the 4th year students specializing in Engineering and Business Management at the Polytechnic University of Bucharest. The sample targeted the final year of the bachelor's cycle within a faculty of the Polytechnic University of Bucharest, this group capturing the activity of young people who have both an engineering and an economic profile and have a certain maturity in thinking. The total number of targeted students was 123. Of the 123 questionnaires sent, 103 responses were received, the response rate being $83.73 \%$. The conceptual framework is presented in Figure 1, which shows the relationships between social networks and the daily use of these social networks. 


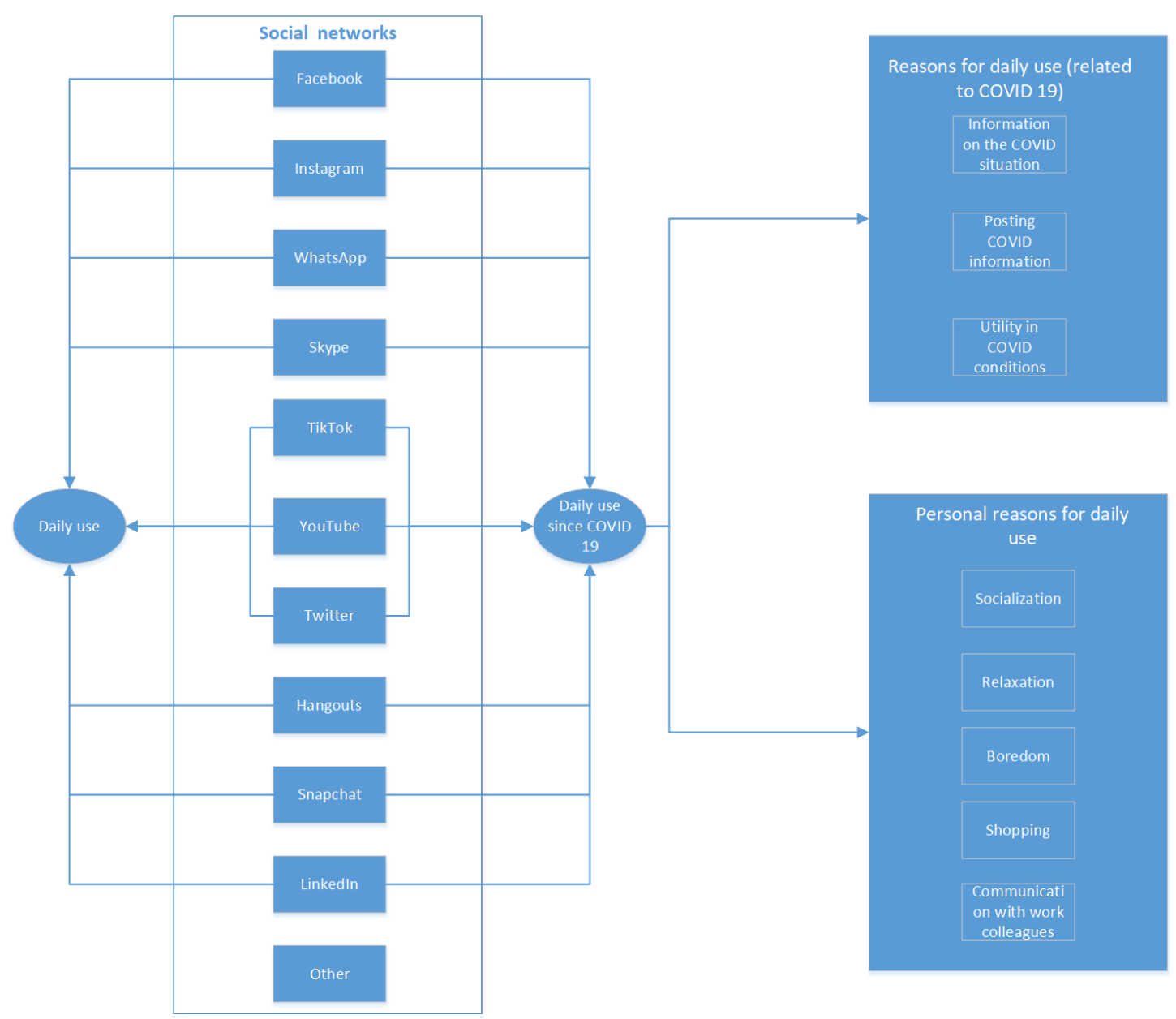

FIGURE 3. THE CONCEPTUAL FRAMEWORK

Source: Author's own contribution

The independent variable is represented by social networks, while the dependent variables are represented by the daily use before COVID-19 and the daily use during COVID-19. In this study, the author used the most known social networks, where a part of them was identified in a study made in 2015 by Ernst \&Young Romania (2015) and also was analysed in another author's research (Barbu \& Militaru, 2018a; Barbu \& Militaru, 2018b). Besides the daily use, the young people's behaviour regarding the use of social media before and after the COVID-19 situation was analysed. For this part, there were considered 2 types of reasons: reasons related to COVID-19 (information on COVID-19 situation, posting COVID-19 information, utility in COVID-19 conditions), and personal reasons (socialization, relaxation, boredom, shopping, communication with work colleagues). The variable Social networks is measured on a nominal scale, while the variables from the categories Changes in daily use of social networks, Reasons related to COVID-19 for daily use of social networks, and Personal reasons for daily use of social networks are measured using a 5-point Likert scale (table 1), these aspects being analyzed for each of the mentioned 
Barbu A.

AN ANALYSIS OF YOUTH BEHAVIOR ON SOCIAL MEDIA NETWORKS DURING THE COVID-19 PANDEMIC. EVIDENCE FROM ROMANIA

types of social networks. For this study, the following control variables were used: age, gender, and degree of employability.

TABLE 1. VARIABLES USED IN THE STUDY

\begin{tabular}{|c|c|c|c|c|c|c|c|}
\hline \multirow{2}{*}{$\begin{array}{l}\text { Main } \\
\text { categories } \\
\text { of variable } \\
\text { Variables }\end{array}$} & \multirow{2}{*}{$\begin{array}{l}\begin{array}{l}\text { Social } \\
\text { networks }\end{array} \\
\begin{array}{l}\text { Social } \\
\text { networks }\end{array}\end{array}$} & \multirow{2}{*}{$\begin{array}{l}\text { Changes in } \\
\text { daily use of } \\
\text { social networks } \\
>\text { The daily use } \\
\text { before COVID- } \\
19 \\
>\text { The daily use } \\
\text { during COVID- } \\
19\end{array}$} & \multirow{2}{*}{$\begin{array}{l}\text { Reasons related to } \\
\text { COVID-19 for daily use } \\
\text { of social networks } \\
\text { > Information on } \\
\text { COVID-19 situation; } \\
>\text { Posting COVID-19 } \\
\text { information; } \\
\text { Utility in COVID-19 } \\
\text { conditions }\end{array}$} & \multirow{2}{*}{$\begin{array}{l}\text { Personal reasons } \\
\text { for daily use of } \\
\text { social networks } \\
>\text { Socialization; } \\
>\text { Relaxation; } \\
>\text { Boredom; } \\
>\text { Shopping; } \\
>\text { Communication } \\
\text { with work } \\
\text { colleaques }\end{array}$} & \multicolumn{3}{|c|}{ Control variables } \\
\hline & & & & & Age & Gender & $\begin{array}{l}\text { Degree of } \\
\text { employability }\end{array}$ \\
\hline Values & $\begin{array}{l}\text { Facebook; } \\
\text { Instagram; } \\
\text { WhatsApp; } \\
\text { Skype; } \\
\text { TikTok; } \\
\text { YouTube; } \\
\text { Twitter; } \\
\text { Hangouts; } \\
\text { Snapchat; } \\
\text { Linkedln; } \\
\text { Other }\end{array}$ & $\begin{array}{l}\text { Never; } \\
\text { Very rarely; } \\
\text { Rarely; } \\
\text { Occasionally; } \\
\text { Frequently; } \\
\text { Very frequently }\end{array}$ & $\begin{array}{l}\text { Not at all; } \\
\text { To a small extent; } \\
\text { To some extent; } \\
\text { To a large extent; } \\
\text { To a very large extent }\end{array}$ & $\begin{array}{l}\text { Not at all; } \\
\text { To a small extent; } \\
\text { To some extent; } \\
\text { To a large extent; } \\
\text { To a very large } \\
\text { extent }\end{array}$ & $\begin{array}{l}18-21 \\
22-25 \\
26-29 \\
30-35\end{array}$ & $\begin{array}{l}\text { Male; } \\
\text { Female }\end{array}$ & $\begin{array}{l}\text { Employed; } \\
\text { Unemployed }\end{array}$ \\
\hline
\end{tabular}

Source: Author's own contribution

\section{RESULTS}

The author collected the respondents' perceptions, the data being analysed using SPSS 20.0 software. The sample consisted of 103 young people aged between 18 and 35 years old. The majority of the respondents was represented by females (77\%), while most of the respondents have between 22 and 25 years (59.2\%), 33\% have between 18 and 21 years old, 5.8\% have between 26 and 29 years old, while $2.9 \%$ have between 30 and 35 years old. In the sample, $45.63 \%$ of the respondents were also employees, their educational level being mentioned in table 2 .

TABLE 2. EDUCATIONAL LEVEL AND DEGREE OF EMPLOYABILITY

\begin{tabular}{|l|l|l|}
\hline Educational level and degree of employability & Frequency & Percent \\
\hline Undergraduate student & 55 & 53.4 \\
\hline Undergraduate student, employee & 20 & 19.4 \\
\hline Master's degree student & 1 & 1 \\
\hline Master's degree student, employee & 15 & 14.6 \\
\hline Employee, with completed higher education & 12 & 11.7 \\
\hline Total & 103 & 100 \\
\hline
\end{tabular}

Source: Author's own contribution

The first phase of the study was to analyse what are the most used social networks. To find the answer, the respondents were asked if they were having social accounts for the following platforms: Facebook, 
Instagram, WhatsApp, Twitter, Snapchat, YouTube, TikTok, Linkedln, Hangouts, Skype, and other platforms. According to the results presented in Figure 4, it can be seen that the most used social media platform is WhatsApp with 100 accounts out of 103. Facebook and Instagram are the next most used social media platforms with 87 and 86 accounts. Also, YouTube is still used by young people, 82 of the respondents having an account for this platform. On the other side, the most unused social networks are Hangouts ( 3 accounts), Twitter (5 accounts), and Linkedln ( 9 accounts).

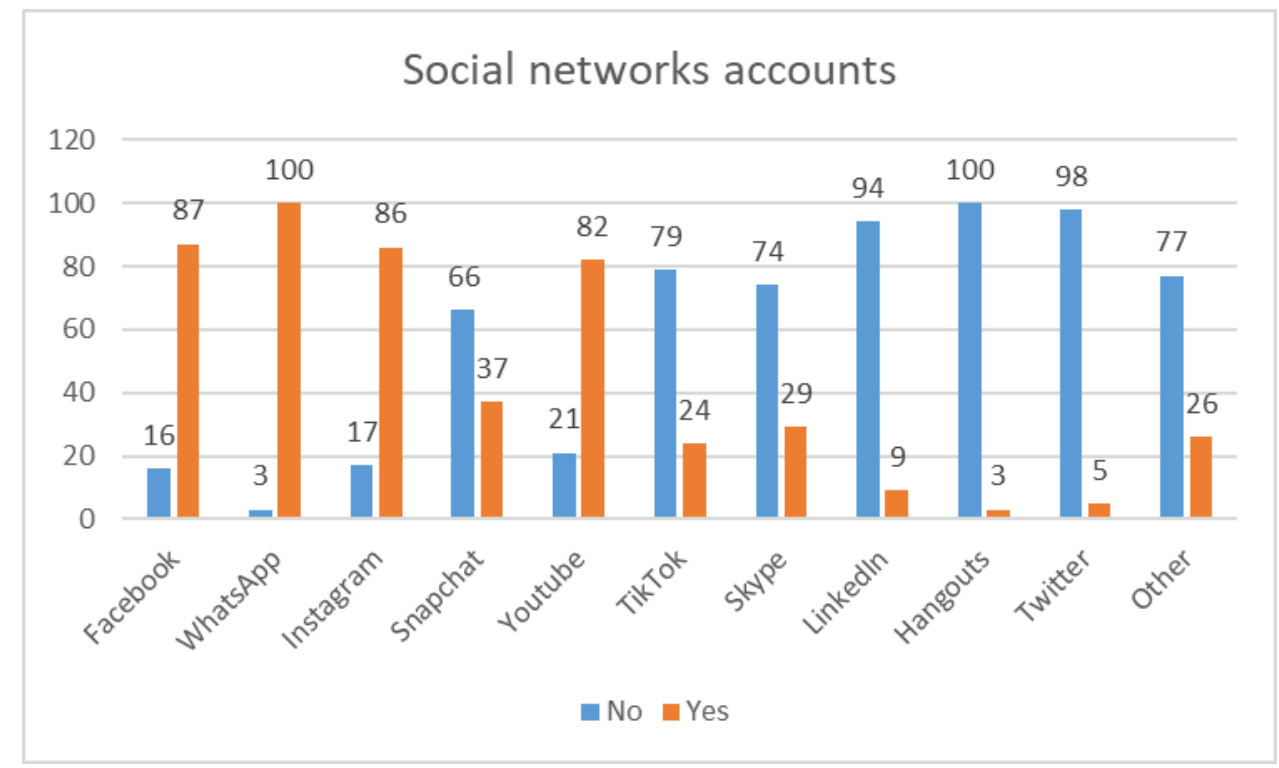

FIGURE 4. SOCIAL NETWORKS ACCOUNTS

Source: Author's own contribution

The next phase consisted is determining the frequency of daily usage of social networks before COVID-19. As a confirmation of the results from above, comes the result presented in figure 5 , where it can be observed that the most used social network is WhatsApp $(93.1 \%$ use this platform frequently and very frequently). The next 2 positions are occupied by Instagram and YouTube, Facebook being on the 4th place in this ranking daily usage. 
Barbu A.

AN ANALYSIS OF YOUTH BEHAVIOR ON SOCIAL MEDIA NETWORKS DURING THE COVID-19 PANDEMIC. EVIDENCE FROM ROMANIA

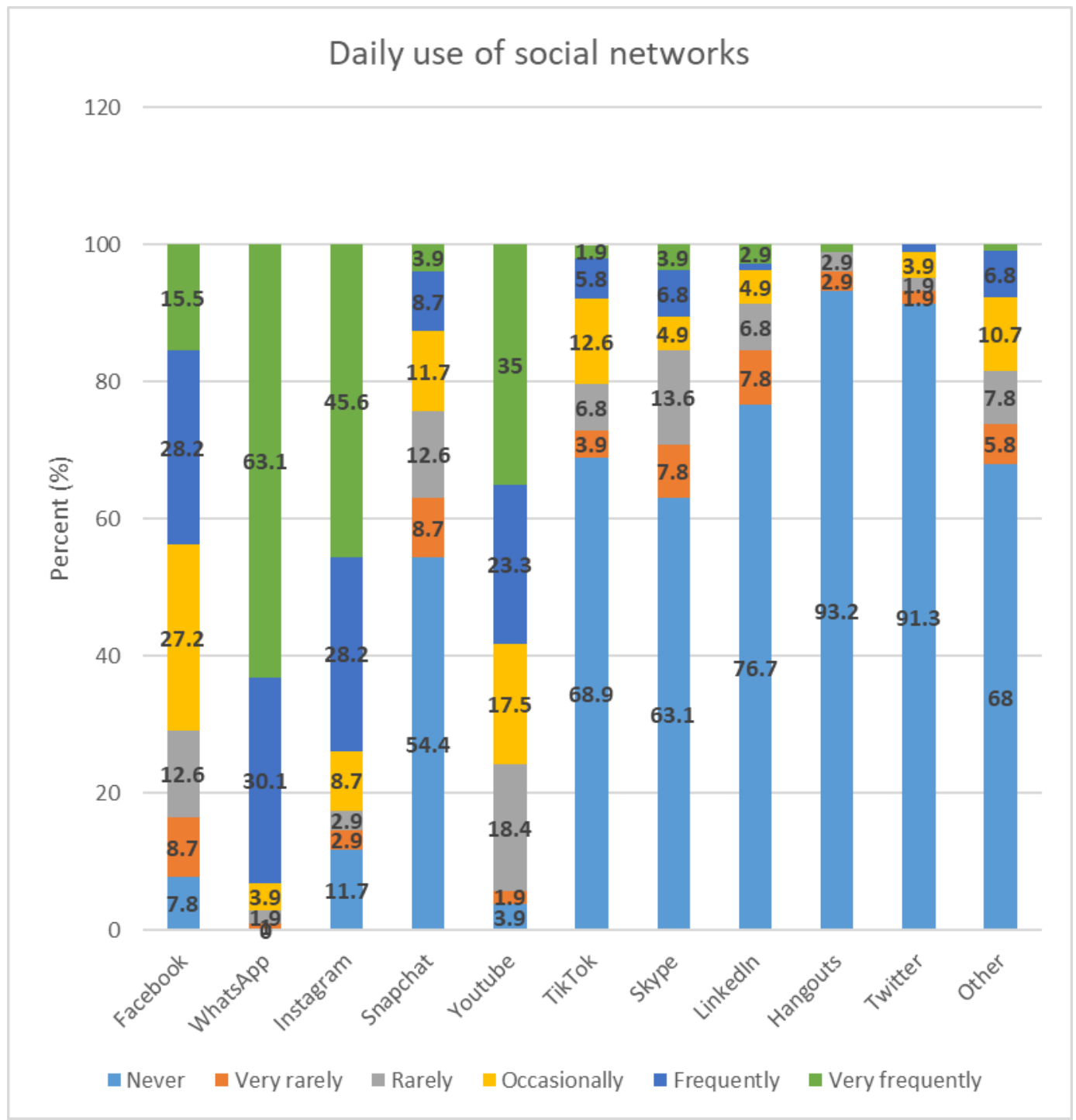

FIGURE 5. DAILY USE OF SOCIAL NETWORKS

Source: Author's own contribution

When it comes to the difference between daily use of social networks before COVID-19 and after the declared pandemic, it can be seen that several platforms have increased their daily usage very frequently (such as Facebook $+10.7 \%$, YouTube $+9.7 \%$, Instagram $+8.7 \%$ ). Also, it is interesting to see that after the COVID-19 appearance, people have started to use other kinds of platforms $(9.7 \%$ increase for people that use other platforms very frequently) 
Barbu A.

AN ANALYSIS OF YOUTH BEHAVIOR ON SOCIAL MEDIA NETWORKS DURING THE COVID-19 PANDEMIC. EVIDENCE FROM ROMANIA

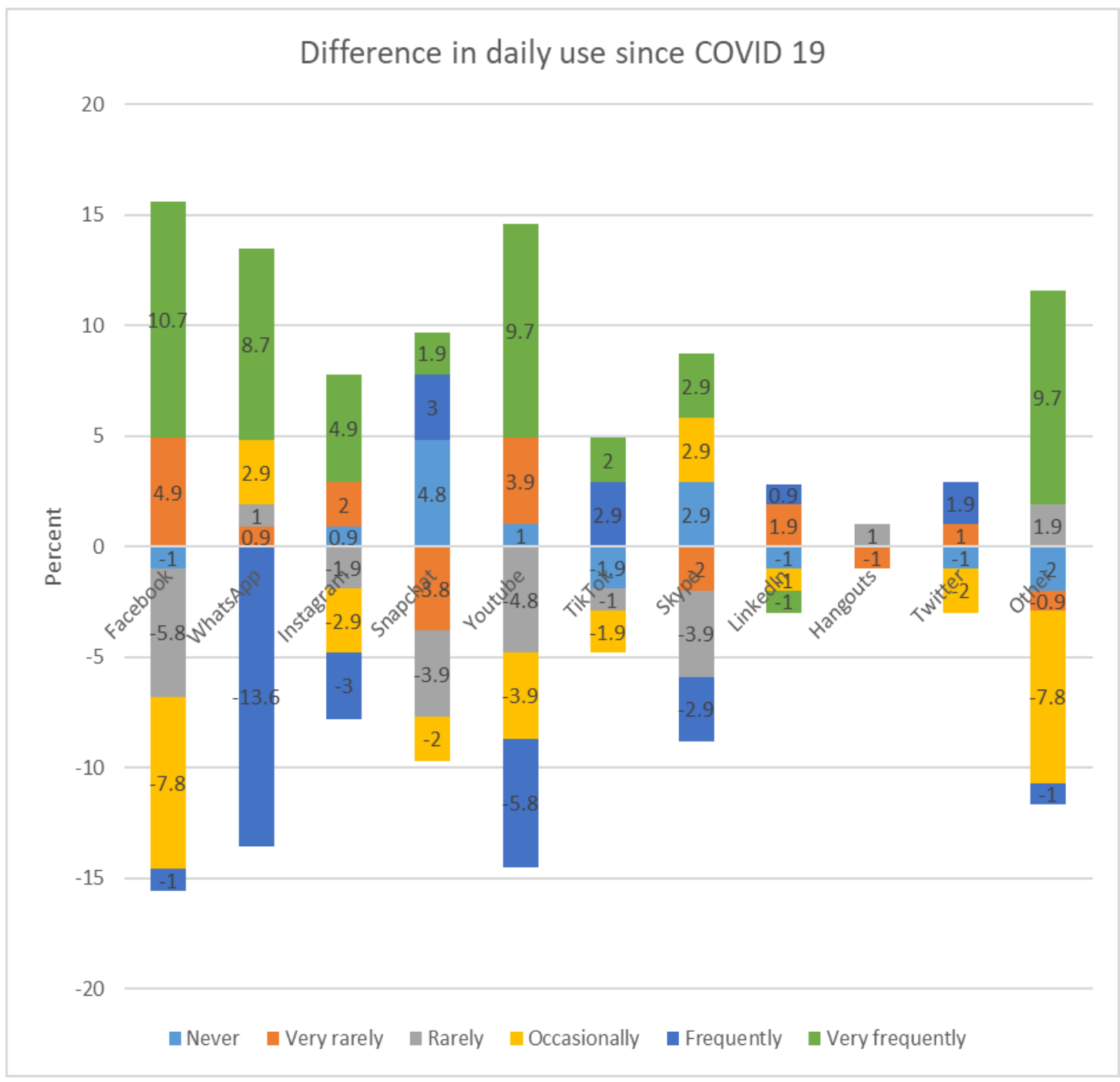

FIGURE 6. THE DIFFERENCE IN DAILY USE SINCE COVID 19

Source: Author's own contribution

To study the correlations between the variables from this paper, the author used the interpretation from the Evans guide (1996), which mentioned that Pearson's values between 0.8 and 1.0 indicate very strong correlations. According to him, values between 0.6 and 0.8 indicate strong correlations, while moderate correlations are indicated by values between 0.4 and 0.6 .

In the pandemic time, there are several moderate direct correlations between the daily use of some social networks and Information on the COVID-19 situation, Posting COVID-19 information, Utility of the social networks in the COVID-19 pandemic. When it comes to reading news about the COVID-19 virus, young people tend to use the Twitter platform to get information from all over the world $(R=.590, p<0.01)$. Also, they use Skype $(R=.529, p<0.01)$ to find out information from other people or Facebook $(R=.508, p<0.01)$, but they also use Linkedln $(R=.411, p<0.01)$, TikTok $(R=.489, p<0.01)$ or Snapchat $(R=.514, p<0.01)$. 
Barbu A.

AN ANALYSIS OF YOUTH BEHAVIOR ON SOCIAL MEDIA NETWORKS DURING THE COVID-19 PANDEMIC. EVIDENCE FROM ROMANIA

TABLE 3. CORRELATIONS BETWEEN SOCIAL MEDIA VARIABLES AND REASONS FOR USING SOCIAL NETWORKS TO BE UP TO DATE WITH THE NEW VIRUS

\begin{tabular}{|c|c|c|c|c|c|c|c|c|c|c|c|}
\hline $\begin{array}{l}\text { Dependent } \\
\text { variables }\end{array}$ & $\begin{array}{c}\text { Indepe } \\
\text { ndent } \\
\text { variabl } \\
\text { es } \\
\end{array}$ & $\begin{array}{c}\text { Facebo } \\
\text { ok }\end{array}$ & $\begin{array}{c}\text { WhatsA } \\
\text { pp }\end{array}$ & Instagram & YouTube & Skype & Linkedln & TikTok & Snapchat & Twitter & Hangouts \\
\hline \multirow{2}{*}{$\begin{array}{l}\text { Information } \\
\text { on the } \\
\text { COVID-19 } \\
\text { situation }\end{array}$} & Du BC & $.470^{* *}$ & $.314^{* \star}$ & $.399^{* \star}$ & $.358^{\star \star}$ & $.498^{* *}$ & $.448^{\star \star}$ & $.471^{* \star}$ & $.509^{\star \star}$ & $.623^{* *}$ & -0.031 \\
\hline & Du C & $.508^{\star *}$ & $.279^{\star \star}$ & $.367^{* *}$ & $.373^{\star *}$ & $.529^{\star \star}$ & $.411^{* *}$ & $.489^{* *}$ & $.514^{\star \star}$ & $.590^{* *}$ & 0.079 \\
\hline \multirow{2}{*}{$\begin{array}{c}\text { Posting } \\
\text { COVID-19 } \\
\text { information }\end{array}$} & Du BC & $.425^{\star *}$ & $.316^{* \star}$ & $.337^{* *}$ & $.204^{*}$ & $.310^{\star *}$ & $.494^{* \star}$ & 0.134 & $.355^{\star \star}$ & 0.183 & -0.031 \\
\hline & Du C & $.503^{\star *}$ & $.287^{\star \star}$ & $.322^{* \star}$ & 0.186 & $.322^{* *}$ & $.469^{\star *}$ & 0.142 & $.334^{\star *}$ & $.297^{\star *}$ & -0.033 \\
\hline \multirow{2}{*}{$\begin{array}{c}\text { Utility in } \\
\text { COVID-19 } \\
\text { situation }\end{array}$} & $\mathrm{Du} B \mathrm{C}$ & $.585^{\star *}$ & $.303^{\star \star}$ & $.476^{\star *}$ & $.472^{\star *}$ & $.482^{\star *}$ & $.492^{\star *}$ & $.298^{\star *}$ & $.436^{\star *}$ & $.423^{* *}$ & -0.066 \\
\hline & Du C & $.549^{* *}$ & $.247^{*}$ & $.500^{* *}$ & $.473^{* *}$ & $.498^{* *}$ & $.493^{\star *}$ & $.344^{* *}$ & $.454^{* *}$ & $.446^{* *}$ & 0.014 \\
\hline
\end{tabular}

Note: Du BC - Daily use before COVID-19; Du C- Daily use in COVID-19 pandemic time

Source: Author's own contribution

To post information about the virus, the respondents tend to use Facebook $(R=.503, p<0.01)$ or Linkedln $(R=.469, p<0.01)$. Young people consider that the following social media platforms have utility in this pandemic time: Facebook $(R=.549, p<0.01)$ Instagram $(R=.500, p<0.01)$, YouTube $(R=.473, p<0.01)$, Skype $(R=.498, p<0.01)$, Linkedln $(R=.493, p<0.01)$ and Twitter $(R=.446, p<0.01)$.

When it comes to daily use (related to COVID-19), there are weak correlations between age and the utility of the Instagram platform in pandemic time $\left(-.260^{\star *}\right)$, posting COVID-19 information $\left(.223^{\star}\right)$ and information of the COVID-19 situation on the Linkedln platform $\left(.224^{*}\right)$ or Twitter platform $\left(.206^{*}\right)$. Those correlations mean that as people get older, they find that Instagram has no utility in this pandemic time but think that Linkedln is a more appropriate platform to post or read news or articles about the virus, as well as the Twitter platform.

TABLE 4. CORRELATIONS BETWEEN SOCIAL MEDIA VARIABLES AND REASONS FOR USING SOCIAL NETWORKS FOR SOCIALIZATION IN A PANDEMIC SITUATION

\begin{tabular}{|c|c|c|c|c|c|c|c|c|c|c|}
\hline & Linkedln & Instagram & Facebook & WhatsApp & Twitter & Snapchat & YouTube & TikTok & Hangouts & Skype \\
\hline $\begin{array}{l}\text { Daily use } \\
\text { before } \\
\text { COVID-19 }\end{array}$ & $.290^{* *}$ & $.723^{\star \star}$ & $.556^{\star \star}$ & $.413^{* *}$ & $.448^{\star \star}$ & $.746^{\star \star}$ & 0.167 & 0.159 & $.706^{* \star}$ & $.667^{\star *}$ \\
\hline $\begin{array}{c}\text { Daily use in } \\
\text { COVID-19 } \\
\text { situation }\end{array}$ & $.260^{* *}$ & $.704^{\star \star}$ & $.607^{* \star}$ & $.379^{* \star}$ & $.456^{* *}$ & $.729^{\star \star}$ & 0.19 & 0.145 & $.739^{\star \star}$ & $.657^{\star *}$ \\
\hline Age & $.246^{*}$ & $-.364^{* *}$ & 0.013 & 0.015 & -0.051 & -0.081 & -0.035 & 0.072 & 0.17 & 0.057 \\
\hline
\end{tabular}

Source: Author's own contribution

Between the daily use of the analysed social networks before and in the COVID-19 pandemic and the use of these social networks for socialization in this time, there are several strong, direct correlations. For example, those strong correlations are between Instagram daily use and socialization $(R=.704, p<0.01)$, Facebook and socialization $(R=.607, p<0.01)$, Snapchat and socialization $(R=.729, p<0.01)$, Hangouts and socialization $(R=.739, p<0.01)$, Skype and socialization $(R=.657, p<0.01)$. There is also a moderate 
correlation between Twitter and socialization $(R=.456, p<0.01)$, the rest of the analysed social media platforms having weak correlations or no correlations with socialization. Regarding the age of the respondents, there is a negative, weak correlation between the age of the respondents and the use of social networks for socialization in the pandemic period $(R=-.364, p<0.01)$, which means that young people are more likely to use Instagram platform for socialization than other platforms.

TABLE 5. CORRELATIONS BETWEEN SOCIAL MEDIA VARIABLES AND REASONS FOR USING SOCIAL NETWORKS FOR COMMUNICATION WITH WORK COLLEAGUES IN THE PANDEMIC SITUATION

\begin{tabular}{|c|c|c|c|c|c|c|c|c|c|c|}
\hline $\begin{array}{c}\text { Communication } \\
\text { with work } \\
\text { colleagues }\end{array}$ & Linkedln & Instagram & Facebook & WhatsApp & Twitter & Snapchat & YouTube & TikTok & Hangouts & Skype \\
\hline $\begin{array}{c}\text { Daily use } \\
\text { before COVID- } \\
19\end{array}$ & $.605^{\star *}$ & $.311^{\star *}$ & $.297^{\star \star}$ & 0.145 & $.319^{\star *}$ & $.388^{* *}$ & 0.117 & 0.051 & $.777^{\star *}$ & $.472^{\star *}$ \\
\hline $\begin{array}{c}\text { Daily use in } \\
\text { COVID-19 } \\
\text { situation }\end{array}$ & $.541^{* *}$ & $.339^{\star *}$ & $.428^{\star *}$ & 0.139 & $.390^{* *}$ & $.359^{\star *}$ & 0.123 & 0.092 & $.774^{\star *}$ & $.571^{\star *}$ \\
\hline Age & $.231^{*}$ & $-.223^{*}$ & -0.126 & 0.084 & 0.04 & 0.028 & -0.036 & -0.014 & 0.011 & $.225^{*}$ \\
\hline
\end{tabular}

Source: Author's own contribution

When it comes to communication with work colleagues in the pandemic situation, it can be seen that the most used platforms are Hangouts $(R=.774, p<0.01)$, Skype $(R=.571, p<0.01)$, and Linkedln $(R=.541$, $p<0.01)$. There are some positive weak correlations between age and the use of Linkedln $(R=.231$, $p<0.05)$, and Skype $(R=.225, p<0.05)$, while there is a negative weak correlation between age and Instagram utilization $(R=-.223, p<0.05)$.

TABLE 6. CORRELATIONS BETWEEN SOCIAL MEDIA VARIABLES AND REASONS FOR USING SOCIAL NETWORKS FOR RELAXATION IN THE PANDEMIC SITUATION

\begin{tabular}{|c|c|c|c|c|c|c|c|c|c|c|}
\hline & Linkedln & Instagram & Facebook & WhatsApp & Twitter & Snapchat & YouTube & TikTok & Hangouts & Skype \\
\hline $\begin{array}{c}\text { Daily use } \\
\text { before } \\
\text { COVID- } \\
19\end{array}$ & $.591^{* *}$ & $.297^{* *}$ & $.664^{* *}$ & $.301^{* *}$ & $.634^{* \star}$ & $.751^{* *}$ & $.638^{* *}$ & $.794^{* \star}$ & -0.022 & $.657^{* *}$ \\
\hline $\begin{array}{c}\text { Daily use } \\
\text { in COVID- } \\
19 \\
\text { situation }\end{array}$ & $.524^{* *}$ & $.277^{* *}$ & $.676^{* *}$ & $.300^{* *}$ & $.700^{\star \star}$ & $.748^{* *}$ & $.615^{\star \star}$ & $.768^{\star \star}$ & -0.023 & $.638^{* *}$ \\
\hline Age & 0.17 & -0.164 & -0.128 & -0.17 & 0.006 & $-.194^{*}$ & -0.167 & -0.133 & 0.03 & 0.021 \\
\hline
\end{tabular}

Source: Author's own contribution

For the relaxing time, the respondents use social media platforms like TikTok $(R=.768, p<0.01)$, Snapchat $(R=.748, p<0.01)$, Twitter $(R=.700, p<0.01)$, Facebook $(R=.676, p<0.01)$, Skype $(R=.638, p<0.01)$, or YouTube $(R=.615, p<0.01)$. For relaxation, they do not use Hangouts, WhatsApp, or Instagram. 
Barbu A.

AN ANALYSIS OF YOUTH BEHAVIOR ON SOCIAL MEDIA NETWORKS DURING THE COVID-19 PANDEMIC. EVIDENCE FROM ROMANIA

TABLE 7. CORRELATIONS BETWEEN SOCIAL MEDIA VARIABLES AND REASONS FOR USING SOCIAL NETWORKS FOR BOREDOM IN THE PANDEMIC SITUATION

\begin{tabular}{|c|c|c|c|c|c|c|c|c|c|c|}
\hline & Linkedln & Instagram & Facebook & WhatsApp & Twitter & Snapchat & YouTube & TikTok & Hangouts & Skype \\
\hline $\begin{array}{l}\text { Daily use } \\
\text { before } \\
\text { COVID- } \\
19\end{array}$ & $.514^{\star \star}$ & $.653^{\star \star}$ & $.556^{\star \star}$ & $.266^{\star \star}$ & $.675^{\star *}$ & $.722^{\star \star}$ & $.384^{* *}$ & $.818^{\star \star}$ & -0.03 & $.503^{\star \star}$ \\
\hline $\begin{array}{l}\text { Daily use } \\
\text { in COVID- } \\
19 \\
\text { situation }\end{array}$ & $.504^{* *}$ & $.658^{* *}$ & $.640^{* *}$ & $.318^{* *}$ & $.757^{\star \star}$ & $.793^{\star *}$ & $.483^{\star *}$ & $.910^{* *}$ & 0.11 & $.537^{\star \star}$ \\
\hline Age & 0.097 & $-.229^{*}$ & -0.121 & -0.117 & 0.091 & -0.141 & -0.177 & $-.220^{*}$ & 0.04 & -0.015 \\
\hline
\end{tabular}

Source: Author's own contribution

One of the reasons that the respondents use social media platforms in the pandemic situation is because they are bored. It seems that TikTok is the most used social media platforms by those that are bored $(R=.910, p<0.01)$, on the second place being Snapchat $(R=.793, p<0.01)$ and on the third one being Twitter $(R=.757, p<0.01)$. Also, there are some direct moderate correlations between the use of social media platforms for boredom and the use of Instagram $(R=.658, p<0.01)$, Facebook $(R=.640, p<0.01)$, Skype $(R=.537, p<0.01)$, or Linkedln $(R=.504, p<0.01)$.

TABLE 8. CORRELATIONS BETWEEN SOCIAL MEDIA VARIABLES AND REASONS FOR USING SOCIAL NETWORKS FOR SHOPPING IN THE PANDEMIC SITUATION

\begin{tabular}{|c|c|c|c|c|c|c|c|c|c|c|}
\hline & Linkedln & Instagram & Facebook & WhatsApp & Twitter & Snapchat & YouTube & TikTok & Hangouts & Skype \\
\hline $\begin{array}{c}\text { Daily use } \\
\text { before } \\
\text { COVID-19 }\end{array}$ & 0.055 & $.771^{* *}$ & 0.116 & 0.063 & $.243^{*}$ & $.208^{*}$ & $.230^{*}$ & $.225^{*}$ & -0.031 & 0.099 \\
\hline $\begin{array}{c}\text { Daily use in } \\
\text { COVID-19 } \\
\text { situation }\end{array}$ & -0.003 & $.763^{* *}$ & $.217^{*}$ & 0.188 & $.298^{* *}$ & 0.187 & $.206^{*}$ & $.211^{*}$ & -0.033 & 0.135 \\
\hline Age & -0.062 & $-.367^{* *}$ & 0.048 & 0.178 & -0.062 & -0.132 & -0.104 & -0.168 & -0.062 & -0.062 \\
\hline
\end{tabular}

Source: Author's own contribution

Regarding the shopping behaviour of the respondents, the author discovered that in the pandemic situation, Instagram was the most used social media platform for shopping $(R=.763, p<0.01)$, the youngest are those who buy more and more often from visiting Instagram platforms $(R=-.367, p<0.01)$. This type of behaviour has also been speculated by so-called influencers, who promote all kinds of things and have all kinds of partnerships with various companies, their profiles offering direct links where you can buy various products or even you can get various discount codes.

\section{CONCLUSIONS}

When it comes to reasons for daily use (related to COVID-19), the author found out that the most used social networks for information on the COVID-19 situation are Twitter, Skype, and Facebook, where 
people can read or hear news from all over the world, from different types of people, experts in the medical domain, politicians, stars, journalists, or the loved ones, those social media platforms being widely known and used worldwide. Taking into account that the virus has affected all countries of the world, people are very curious to know what is happening in other states, how the virus behaves, and how it affects people in different parts of the globe. On one hand, the respondents use social networks to post news and their opinion about COVID-19, using Facebook to openly express their opinions, beliefs, to react to other people's posts. They also use Linkedln, some of them trying to seem concerned about what is happening to be able to "sell" a better image in the eyes of employers and potential employees, "playing" the role of involved, informed people. Thus, they use this context to create a favourable image in front of others. On the other hand, the respondents consider that many of the social media platforms have a certain utility in this pandemic time, but the correlations identified in this regard are at most moderate, suggesting that being active on such a platform, however, does not help much to overcome this difficult period we are in. For the part regarding personal reasons for the daily use of social networks, the findings of this study show that socialization is the most used reason in this period, being followed by reasons like relaxation and boredom. The most used social networks for relaxation are Instagram, Snapchat, Hangouts, Skype, Facebook, and even WhatsApp or Twitter, these platforms allow writing, oral, or video communication, as well as posting or distributing various news, photos or videos. In this period, those who want to communicate with work colleagues use Hangouts, Skype, or Linkedln platforms, these platforms being agreed upon and implemented in most companies or even universities as official communication media.

If respondents wanted to use social networks to relax or simply because they were bored, they used almost every kind of social media platform, except Hangouts. Surprising is that lately, the TikTok platform began to become increasingly more interesting for users, this platform being one of the most used social networks for relaxation in the analysed period. TikTok is also used most often when it comes to young people's boredom, being followed by the Snapchat platform.

The most interesting aspect presented in this paper is related to the buying behaviour of the respondents who use social networks. The results show that most people buy various things directly from Instagram, either they buy the products directly from the official pages of the companies or they are redirected to them from the pages of certain celebrities or influencers. Observing these trends, many young people try to create a certain digital content on Instagram, to gather as many followers as possible to attract the attention of companies with which to enter into partnerships, dreaming of becoming influencers and more easily earn money from the various affiliations they make.

Considering these aspects, companies should be more and more present on social networks, being always visible, active, posting various videos and messages to attract the Internet users' attention. Also, the virtual space is a space where people communicate a lot and share their opinions, which is why they 
Barbu A.

AN ANALYSIS OF YOUTH BEHAVIOR ON SOCIAL MEDIA NETWORKS DURING THE COVID-19 PANDEMIC. EVIDENCE FROM ROMANIA

should find the right people to represent their goods and services and collaborate with various influencers in this regard. Because social network Instagram brings many visitors and potential customers to a company, organizations should allocate a separate budget for online promotion, emphasizing its presence on Instagram. Furthermore, their presence on Facebook is very important, this platform being that one that also relies heavily on customer feedback and people's reactions to its posts.

Although the results presented provide important indications regarding how social networks are used during this pandemic period, the study must be treated carefully, as it also has limitations. The number of respondents is small compared to the young population in Romania, in Bucharest, which makes this study a pilot one. Respondents included both people who work and people who do not work in some companies, which is why it is possible that in some questions, young people have made the analogy with teamwork in faculties where they are students or to have answered thinking about how they could help them if they were in the position of employees. The answers collected target the perceptions of the respondents, which is why some answers may be influenced by their age, gender, or status.

As future directions, the author intends to continue the study on the behaviour of the young population in this period influenced by the presence of the COVID-19 virus, researching aspects related to how social networks and educational platforms have influenced students' academic results between February and June 2020.

\section{REFERENCES}

Adhikari, S., Meng, S., Wu, Y. et al. (2020). Epidemiology, causes, clinical manifestation and diagnosis, prevention and control of coronavirus disease (COVID-19) during the early outbreak period: a scoping review. Infect Dis Poverty 9, 29 (2020). https://doi.org/10.1186/s40249-020-00646-x

Al Hasan SM, Saulam J, Kanda K \& Hirao T. (2020). The novel coronavirus disease (COVID-19) outbreak trends in mainland China: a joinpoint regression analysis of the outbreak data from January 10 to February 11, 2020. [Preprint]. Bull World Health Organ. E-pub: 17 February 2020

Anastasiei, B., Dospinescu, N. (2017). Facebook Advertising: Relationship between Types of Message, Brand Attitude and Perceived Buying Risk. Annals of the "Constantin Brâncuşi” University of Târgu Jiu, Economy Series, Issue 6/2017, 18-26

Ballard, P. J., Hoyt, L. T., \& Pachucki, M. C. (2019). Impacts of adolescent and young adult civic engagement on health and socioeconomic status in adulthood. Child development, 90(4), 1138-1154.

Barbu, A.; Militaru, G. (2018). Determining the Differences between Companies and Customers from the Perspective of Using Social Media Networks, Conference: 6th International Academic Conference on Strategica - Challenging the Status Quo in Management and Economics Location: Bucharest, ROMANIA, Date: OCT 11-12, 2018, Strategica: Challenging the Status Quo in Management And Economics, Book Series: Strategica, 881-893

Barbu, A.; Militaru, G. (2018). Investigating the Innovation Potential of a Company Obtained through Social Media, Conference: 12th International Management Conference on Management Perspectives in the 
Digital Era (IMC), Location: Bucharest, ROMANIA, Date: NOV 01-02, 2018, Proceedings of the 12th International Management Conference: Management Perspectives in the Digital Era (IMC 2018), Book Series: International Management Conference, 247-258

Chao, M., Chen, X., Liu, T., Yang, H., \& Hall, B. J. (2020). Psychological distress and state boredom during the COVID-19 outbreak in China: the role of meaning in life and media use. European Journal of Psychotraumatology, 11(1), 1769379.

Cohen, R., Newton-John, T., and Slater, A. (2018). Selfie'-objectification: the role of selfies in selfobjectification and disordered eating in young women. Computers in Human Behavior, 79 (2), 68-74

Daoud, R., Starkey, L., Eppel, E., Vo, T. D., \& Sylvester, A. (2020). The educational value of internet use in the home for school children: A systematic review of literature. Joumal of Research on Technology in Education, 1-22.

Ernst \& Young Romania (2015). Social media şi mediul de afaceri românesc 2015 [Social Media and the Romanian Business Environment 2015]. Retrieved August 16, 2017, from http://www.eyromania.ro/2014/noutati/articole/74-dintre-companiile-din-rom\%C3\%A2niautilizeaz\%C4\%83-re\%C5\%A3elele-sociale-pentru-promovare

Evans, J.D. (1996). Straightforward statistics for the behavioral sciences. Pacific Grove, CA: Brooks/Cole Publishing

Kaplan, A. M., and Haenlein, M. (2010). Users of the world, unite! The challenges and opportunities of Social Media. Business horizons.53(1), 59-68.

Khodabandeh, A., \& Lindh, C. (2020). The importance of brands, commitment, and influencers on purchase intent in the context of online relationships. Australasian Marketing Journal (AMJ). doi:10.1016/j.ausmj.2020.03.003

Leonardi, P. M., Huysman, M., and Steinfield, C. (2013). Enterprise social media: Definition, history, and prospects for the study of social technologies in organizations. Journal of Computer-Mediated Communication.19(1), 1-19.

Michaelidou, N., Siamagka, N. T., and Christodoulides, G. (2011). Usage, barriers and measurement of social media marketing: An exploratory investigation of small and medium B2B brands. Industrial marketing management.40(7), 1153-1159.

Pizzoli, S.M.F., Marzorati C, Mazzoni D, Pravettoni G (2020). An Internet-Based Intervention to Alleviate Stress During Social Isolation with Guided Relaxation and Meditation: Protocol for a Randomized Controlled Trial. JMIR Res Protoc 2020;9(6): e19236

Slovic, P., Peters, E., Finucane, M. L., \& MacGregor, D. G. (2005). Affect, risk, and decision making. Health Psychology, 24(4, Suppl), 35-40.

Stockdale, L. A., \& Coyne, S. M. (2020). Bored and online: Reasons for using social media, problematic social networking site use, and behavioral outcomes across the transition from adolescence to emerging adulthood. Journal of Adolescence, 79, 173-183.

The Statista Portal (2020). Most popular social networks worldwide as of July 2020, ranked by number of active users (in millions) Retrieved August 22, 2020, from https://www.statista.com/statistics/272014/global-social-networks-ranked-by-number-of-users/

World Health Organization (2020). Coronavirus disease (COVID-2019) press briefings, Retrieved August 16, 2020, from https://www.who.int/emergencies/diseases/novel-coronavirus-2019/mediaresources/press-briefings

World Health Organization (2020). WHO Coronavirus Disease (COVID-19) Dashboard, Retrieved July 30, 2020, from https://covid19.who.int/ 